\title{
Mechanism of firmness loss in guava cv. Pedro Sato during ripening at room temperature
}

\author{
Mariana Aparecida BRAGA ${ }^{1 \star}$, Tamara Rezende MARQUES ${ }^{1}$, Anderson Assaid SIMÃO ${ }^{1}$, \\ Lucimara Nazaré Silva BOTELHO ${ }^{1}$, Laís Salviano de OLIVEIRA ${ }^{1}$, Celeste Maria Patto de ABREU ${ }^{1}$
}

\begin{abstract}
Guava (Psidium guajava L.) is fruit with very short shelf life due to associated with the loss of firmness in the pulp and information on the activity of enzymes that degrade pectic substances, as well as the amount of pectin, is very contradictory and not clearly defined. This work showed that the firmness of the fruit decreased sharply on the first four days of ripening. The identified phenolic compounds had their content increased with fruit maturation. The addition of the enzymes cellulase and hemicellulase in the pectin extraction in fruits of Psidium guajava revealed higher contents of this polyssacaride that the ones reported in literature, highlighting pectin as the responsible for the firmness of these fruits at more adequate contents. $\beta$-D-glucosidase was identified as one of the responsible enzymes for the maturation of $P$. guajava fruits. Thus, studies about possible inhibitory effects of this enzyme in $P$. guajava fruits may reveal an important tool to reduce pectin release and early maturation of these fruits.
\end{abstract}

Keywords: Psidium guajava; pectin; phenolic compounds; $\beta$-D-glucosidase; esterase.

Practical Application: Guava is a highly perishable fruit and information on the activity of enzymes that degrade pectic substances and the amount of pectin, not are clearly defined. This work showed that the firmness of the Guava decreased with ripenig, that pectin is responsible for the firmness and that the content phenolic compounds increased with fruit maturation. $\beta$-D-glucosidase was identified as one of the responsible enzymes for the maturation, thus possible inhibitory effects of this enzyme may reduce pectin release and early maturation of these fruits.

\section{Introduction}

The red guavas are widely produced in Brazil, being the largest producer. Exports are destined for the European market without any post-harvest treatment (Vieira et al., 2014). However, the transport and storage period of guava (Psidium guajava L.) is limited by the very short shelf life after harvest and by highly perishability, which is associated with the loss of firmness in the pulp (Gonçalves et al., 2016).

Pectin polymers are considered primarily responsible for the firmness of green fruits (Abreu et al., 2012a) and their degradation is one of the most notable events during ripening and softening of the fruit. In guavas, it is not different. However, the content of pectins described in the literature for guava pulp (about 2.5\% fresh weight and 15\% dry weight) (Xisto et al., 2004; Linhares et al., 2007) is very small to be considered the main responsible for the maintenance of firmness. According to Abreu et al. (2012a), throughout the ripening of guava cv. Pedro Sato, pectin from the cell wall gradually migrates into the cell, probably in vacuoles, and the function of this migration is still unexplained.

Chemical modifications, mainly related to the contents of carbohydrates, organic acids, phenolic compounds and pectins, the degradation of cell wall components and decrease in fruit integrity are observed during fruit maturation (Vilas Boas et al., 2013; Dolkar et al., 2017). These changes are commonly associated with the action of specific enzymes, such as pectin methyl esterase (PME) and polygalacturonase (PG), enzymes capable of degrading pectic substances localizadas found in the cell wall and in the middle lamella of parenchymal cells from muitosvarious fruits and vegetables (Chitarra \& Chitarra, 2005). However, according to Linhares et al. (2007) is not found or it is very low the activity of PG, making the information about the activity of these enzymes contradictory, and the mechanisms that control ripening not clearly defined. Thus, the knowledge of changes occurring during this process is important to clarify and establish scientific bases which enable the development of new post-harvest technologies, increasing, therefore, the shelf life of these fruits (Abreu et al., 2012a).

Given the above, in order to elucidate the rapid decrease in firmness during the ripening of guava cv. Pedro Sato, the present study had as objective to evaluate the composition of the cell wall of guava, especially pectins, the interconnections between their chains and bound phenolic compounds, as well 
as the enzymatic processes involved in the release and transport of polymers into the cell.

\section{Materials and methods}

\subsection{Preparation of the fruits}

Guavas (Psidium guajava L.) from cv. Pedro Sato were manually picked early in the morning at the half-mature ripening stage (light green coloration) in a commercial orchard located in the municipal district of Lavras, Minas Gerais. The harvested fruits were selected based on size, color, absence of physiological and mechanical injuries, washed in tap water and separated into 9 groups of 9 fruits for the composition of the treatments. The fruits were sanitized in a $1 \%$ sodium hypochlorite solution at room temperature for 5 minutes. They were identified and stored on a shelf and kept for a period of 8 days at a temperature and relative humidity ranging between $27^{\circ} \mathrm{C} \pm 1{ }^{\circ} \mathrm{C}$ and $53 \% \pm 1 \%$, respectively.

The samples were prepared on the day of harvest and every day until the end of the ripening period; the fruits were chopped into pieces of approximately $1 \mathrm{~cm}^{3}$ and the endocarp was removed. The fruits were then packed in plastic bags separately in three groups of three fruits each, and the fruits were placed in the freezer for later analyses.

\subsection{Physical and chemical analyses}

The analysis of firmness was performed using a digital penetrometer (TA-XT2 $\mathrm{i}^{\circledast}$ texture analyzer) with a $3 \mathrm{~mm}$ flat tip. Two equidistant readings were taken in the equatorial region of each fruit. The results were expressed in Newtons $(\mathrm{N})$.

The phenolic compounds were quantified using the Folin-Denis reagent (Association of Official Analytical Chemists, 2012). The results were expressed as $\mathrm{mg}$ tannic acid $\mathrm{g}^{-1}$ sample.

\subsection{Extraction and quantification of pectin}

Total and soluble pectin

The technique proposed by McCready \& McComb (1952), was used to extract the total and soluble pectin and quantified by carbazole reaction, according to Bitter \& Muir (1962). The results were expressed in g galacturonic acid per $100 \mathrm{~g}$ guava pulp.

\section{Insoluble pectin}

The contents of insoluble pectin were obtained in three different ways. In the first, they were determined by the difference between the contents of total and soluble pectin, quantified by the method of McCready \& McComb (1952).

In the second method, insoluble pectin was extracted by the method proposed by McCready \& McComb (1952), with modifications. Cellulase $\left(5 \mathrm{mg} \mathrm{mL}^{-1}\right)$ was added to the residue of soluble pectin in $20 \mathrm{~mL}$ of $0.1 \mathrm{~mol} \mathrm{~L}^{-1}$ phosphate-citrate buffer, at $\mathrm{pH}$ 4.8. This homogenate was stored for one night in a water bath at $30^{\circ} \mathrm{C}$. Subsequently, the samples were centrifuged at $5,000 \mathrm{x} g$ at $25^{\circ} \mathrm{C}$ for 10 minutes. $50 \mathrm{mg}$ pectinase were added to the supernatant, and it was stirred for 30 minutes at $30^{\circ} \mathrm{C}$; therefore, insoluble pectin was obtained in the supernatant fraction. $10 \mathrm{~mL}$ of $0.11 \mathrm{~mol} \mathrm{~L}^{-1}$ EDTA solution, at $\mathrm{pH} 11$, were added to the sediment. After 30 minutes, the $\mathrm{pH}$ was adjusted to 5 with $10 \%$ acetic acid, and $50 \mathrm{mg}$ pectinase were added. It was then stirred for one hour at $30{ }^{\circ} \mathrm{C}$ and the volume was completed to $20 \mathrm{~mL}$ EDTA; insoluble pectin was obtained in the supernatant fraction. These pectic substances were quantified by the technique standardized by Bitter \& Muir (1962).

In the third method, the same procedures described above were carried out in the first modification. However, cellulase ( $5 \mathrm{mg} \mathrm{mL}^{-1}$ ) was added to the residue of soluble pectin, as well as hemicellulase $\left(5 \mathrm{mg} \mathrm{mL}^{-1}\right)$, in $20 \mathrm{~mL}$ of $0.1 \mathrm{~mol} \mathrm{~L}^{-1}$ phosphate-citrate buffer, at $\mathrm{pH} 4.8$, and the analysis was carried out in the same way.

\subsection{Identification and quantification of phenolic compounds}

The phenolic standards and guava extract were separated using using a Shimadzu UHPLC chromatograph (Shimadzu Corporation, Kyoto, Japan) equipped with two LC-20AT high-pressure pumps, an automatic injector with an SIL-20A auto sampler, an SPD-M20A UV-Vis detector and Shim-pack VP-ODS-C18 $(250 \mathrm{~mm} \times 4.6 \mathrm{~mm})$ column, connected to a Shim-pack Column Holder $(10 \mathrm{~mm} \times 4.6 \mathrm{~mm})$ pre-column (Shimadzu, Japan).

The analysis were performed, using a mobile phase constituted of the following solutions: $2 \%$ acetic acid in water (A) and methanol:water:acetic acid (70:28:2 v/v/v) (B), for a total time of $65 \mathrm{~min}$ at $40{ }^{\circ} \mathrm{C}$, flux of $1 \mathrm{~mL} \mathrm{~min}^{-1}$, wavelength of $280 \mathrm{~nm}$, and injection volume of $20 \mu \mathrm{L}$ in a gradient-type system (100\% solvent A from 0.01 to $5 \mathrm{~min} ; 70 \%$ solvent A from 5 to $25 \mathrm{~min}$; $60 \%$ solvent A from 25 to $43 \mathrm{~min}$; $55 \%$ solvent A from 43 to $50 \mathrm{~min}$; and $0 \%$ solvent $A$ for $10 \mathrm{~min}$ ) until the end of the run. Solvent A was increased to $100 \%$, seeking to maintain a balanced column (Marques et al., 2016).

The phenolic standards used as identification parameters were gallic acid, catechin, epigallocatechin gallate, epicatechin, syringic acid, $p$-coumaric acid, ferulic acid, salicylic acid, resveratrol and quercetin. The phenolic compounds in the extract were identified by comparison with retention times of standards and quantification was performed by the construction of analytical curves obtained by linear regression.

\subsection{Enzymatic analyses}

\section{$\beta$-D-glucosidase with salicin}

The extraction of $\beta$-D-glucosidase was performed according to Linhares et al. (2007), and the enzymatic activity was determined according to Noelting \& Bernfeld (1948), with the substitution of the substrate $\mathrm{p}$-nitrophenyl- $\beta$-D-glucopyranoside ( $\mathrm{pNP} \beta \mathrm{G}$ ) by $0.01 \mathrm{~mol} \mathrm{~L}^{-1}$ salicin, in a $0.1 \mathrm{~mol} \mathrm{~L}^{-1}$ phosphate-citrate buffer and $\mathrm{pH}$ 5.5. The results were expressed as milliunits $(\mathrm{mU})$ per $g$ of guava pulp, which corresponds to the formation of a micromole of glucose per minute under the assay conditions. 


\section{$\beta$-D-glucosidase with $p N P \beta G$}

The extraction and quantitation of $\beta$-D-glucosidase was performed according to Linhares et al. (2007), using $0.01 \mathrm{~mol} \mathrm{~L}^{-1}$ p-nitrophenyl- $\beta$-D-glucopyranoside ( $\mathrm{pNP} \beta \mathrm{G})$ as a substrate, in a $0.1 \mathrm{~mol} \mathrm{~L}^{-1}$ phosphate-citrate buffer, at $\mathrm{pH} 5.5$. The activity of $\beta$-D-glucosidase was expressed as milliunits (mU), which corresponds to the formation of a nanomol of p-nitrophenol per minute under the assay conditions.

\section{Esterase}

The extraction of esterase from the guava pulp was performed according to Linhares et al. (2007), with modifications. The homogenate (HOM) was centrifuged at $10,000 \mathrm{xg}$ at $4{ }^{\circ} \mathrm{C}$ for 10 minutes, and the supernatant (SOB1) was the soluble esterase extract. The sediment (SED1) containing esterase membrane was again homogenized in the same buffer at a $1: 4(\mathrm{w} / \mathrm{v})$ ratio, added with $2 \%$ Triton X-100. After 24 hours at $4{ }^{\circ} \mathrm{C}$, the homogenate was centrifuged at $10,000 \mathrm{xg}$ at $4{ }^{\circ} \mathrm{C}$ for 10 minutes, and the supernatant (SOB2) was used as solubilized esterase. Sediment 2 (SED2) was used as non-solubilized esterase. The extracted fractions were used as enzyme extract.

The enzymatic activity was determined according to Linhares et al. (2007), using $4.46 \mathrm{mmol} \mathrm{L}^{-1} \alpha$-naphthyl acetate as a substrate in $0.22 \mathrm{~mol} \mathrm{~L}^{-1}$ phosphate buffer, at $\mathrm{pH}$ 6.5. One unit of enzyme was defined as the amount of enzyme capable of catalyzing the release of a micromole of $\alpha$-naphthol per minute, under the assay conditions. The results were expressed as milliunits (mU) per $g$ of fresh pulp.

\subsection{Experimental design}

A completely randomized design (CRD) was used, with 9 treatments $(0,1,2,3,4,5,6,7$, and 8 days of ripening). The experimental portion consisted of 3 fruits with 3 repetitions for each treatment. The results were submitted to the variance analysis using the software SANEST (Zonta \& Machado, 1991). When significant, data were subjected to regression analysis.

\section{Results and discussion}

\subsection{Firmness and phenolic compounds}

The Figure 1 shown the loss of firmness of guava cv. Pedro Sato during the eight days of maturation at a temperature of $27^{\circ} \mathrm{C}$. On the day of harvest (unripe fruit, light green peel), firmness was $28.6 \mathrm{~N}$, and it sharply decreased until the fourth day of ripening $(4.54 \mathrm{~N}$, a reduction of $84 \%)$, already with the fruits not very attractive for the consumption.

Changes in pectins of the primary cell wall and their interactions have been associated with the main causes of texture changes, resulting in a reduction in firmness during fruit ripening (Paniagua et al., 2017). During ripening the loss of firmness is due to the activity of hydrolytic enzymes, especially the activity of pectin methyl esterases (PME) and polygalacturonases (PG), which cause an intense solubilization of pectins in the cell wall (Wei et al., 2015; Gayathri \& Nair, 2017). However, Linhares et al. (2007) did not observe the activity of PG in guava cv. Pedro

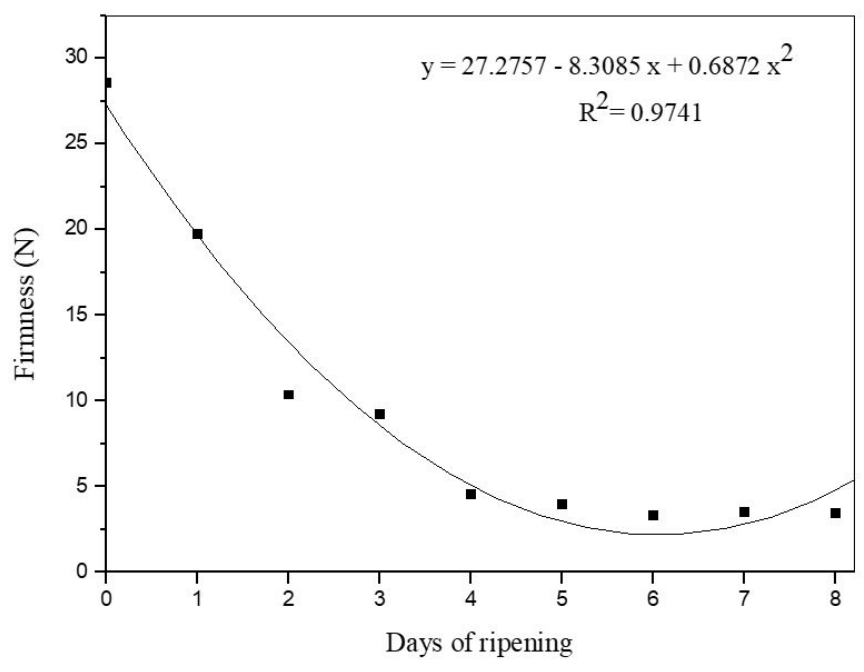

Figure 1. Firmness of guava cv. Pedro Sato during eight days of ripening, at room temperature.

Sato; therefore, the explanation for the decrease in firmness is still unknown.

The results of this study are similar to those reported by Botelho et al. (2016) and Abreu et al. (2012a), who reported a reduction of 70 and $73 \%$, respectively, in the firmness of guava $\mathrm{cv}$. Pedro Sato, during four days of storage at room temperature. Other guava cultivars also showed similar reductions, ranging between $85 \%$ for cv. Paluma (Cavalini et al., 2015), 78\% for cv. Cortibel (Werner et al., 2009) and 80\% for cv. Allahabad Safeda (Gill et al., 2016).

The behavior of phenolic compounds during ripening at a temperature of $27^{\circ} \mathrm{C}$ was increasing over the days. The variation for the green (day 0 ) and ripe (day 8 ) fruit was respectively: 259.80 and $328.20 \mathrm{mg}$ tannic acid per $100 \mathrm{~g}$ fresh pulp, which corresponds to an increase of $26.3 \%$ in the content of these compounds. The increase in the content of phenolic compounds in post-harvest can often be related to biotic and abiotic stresses, which induce the secondary metabolism of the fruit, with an increase in the production of these compounds (Severo et al., 2010). It is also possible to correlate this increase in phenolic compounds with their release, with cell wall degradation. Phenolic compounds bound to wall polysaccharides are released, and can be detected by the extraction technique.

\subsection{Pectin contents}

The content of soluble pectin increased with ripening, ranging from $0.13 \%(\mathrm{w} / \mathrm{w}$ ) to $0.55 \%$ galacturonic acid (Figure 2 ). Throughout ripening, there is an increase in soluble pectin, which is usually accompanied by a decrease in protopectin, indicating that solubilized pectins come from polymers more firmly integrated into the cell wall, and possibly to hemicellulose (Paiva et al., 2009; Ghai et al., 2016).

Through analyses of sugar fractionation and percent composition of guava cv. Pedro Sato, Abreu et al. (2012b) suggested that the amount of pectin in guava should be higher than $2.5 \%$ in fresh weight (or 15\% dry weight). Given these 
results, a new step in the extraction of pectin was proposed, in the two modified methods by McCready \& McComb (1952), that is, the treatment of the residue after the determination of soluble pectin, with cellulase and pectinase in the fractions supernatant and sediment, obtaining insoluble pectin, and cellulase, hemicellulase and pectinase were used in the other treatment, under the same conditions.

When the two modified extraction methods were used, it was possible to observe an increase in the amount of insoluble pectin (Table 1); however, a behavior similar to the original method was maintained, that is, insoluble pectin decreased during ripening.

The enzymes hemicellulase and cellulase, used in the extraction of pectin, caused a higher degradation in the cell wall structure of the fruit and released other pectin molecules, which were hydrolyzed by pectinase, thus increasing the observed content of pectin. These results demonstrate that a large amount of pectin is trapped in the cell wall of the fruit, using the extraction proposed by McCready \& McComb (1952), while the addition of the enzymes cellulase and hemicellulase results in a significant increase in the content of pectins.

The content of total pectin during the ripening of guava, by the method of McCready \& McComb (1952), was approximately $1.80 \%$ galacturonic acid, a small amount to be considered one of the main responsible for the loss of firmness in fruits. However, extractions with cellulase and pectinase, as well as with cellulase, hemicellulase and pectinase, showed total pectin levels near $4.45 \%$ and $6.71 \%$ galacturonic acid, respectively, higher than those observed using the method of McCready \& McComb (1952). The extraction with cellulase, hemicellulase and pectinase was more efficient in the extraction of pectin, showing a greater involvement of this polysaccharide in cell wall firmness.

There is evidence in the literature that pectin polymers, considered the main responsible for the firmness of green and ripe fruits, can present their glycosidic chains interconnected by phenolic compounds (Taiz and Zeiger, 2013). Parr et al. (1997) found that phenolic compounds in the cell wall can influence the physical properties of carrot tissues. On the other hand, Tsai et al. (2010) pointed out that the interaction between phenolic compounds and pectin is an important factor in the maintenance of the texture of guava during the thermal processing.

In order to investigate changes in pectins of the cell wall of guava during ripening, the identification analysis of phenolic compounds was performed by HPLC. The objective was to verify if phenolic compounds undergo changes during ripening and if these changes are related to the release of pectin polymers, being responsible for the decrease in fruit firmness.

The following phenolic compounds were identified in guava pulp during eight days of ripening: gallic acid, catechin and epigallocatechin gallate (Figure 3 ).

Their concentrations, in $\mathrm{mg} 100 \mathrm{~g}^{-1}$ pulp, ranged during the eight days of ripening: gallic acid $(0.84 \pm 0.03$ to $1.23 \pm 0.02)$, catechin $(0.88 \pm 0.02$ to $1.78 \pm 0.01)$ and epigallocatechin gallate $(1.50 \pm 0.02$ to $2.34 \pm 0.02)$. This increase in peaks may characterize that phenolic compounds are interconnected to

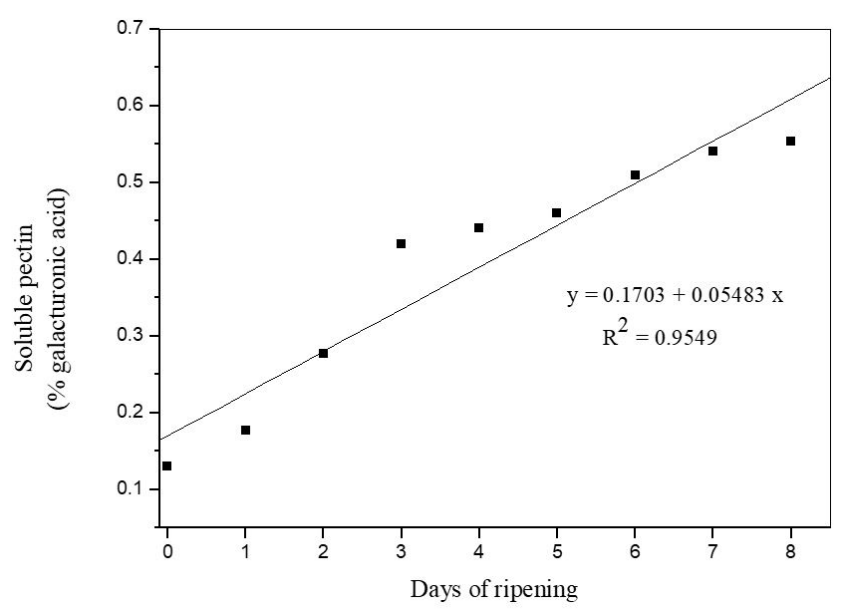

Figure 2. Soluble pectin in guava cv. Pedro Sato during eight days of ripening.

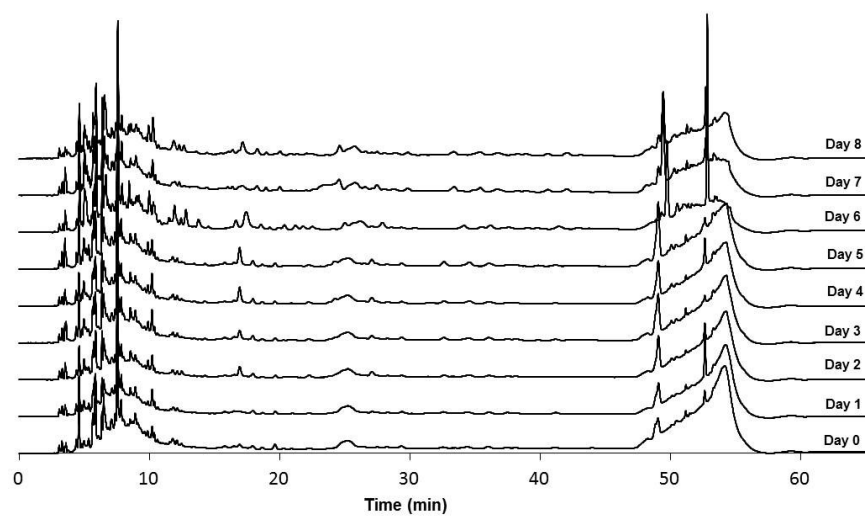

Figure 3. Chromatogram of phenolic compounds in the guava pulp extract during eight days of ripening. Average retention times of the identified phenolic compounds: gallic acid (time $=6.52 \pm 0.02$ ); catechin $($ time $=10.41 \pm 0.04)$; epigallocatechin gallate (time $=12.16 \pm 0.07)$.

Table 1. Average contents (\%) of insoluble pectin fractions (PI) according to three different extraction methods during the ripening of guava cv. Pedro Sato.

\begin{tabular}{cccc}
\hline Days & $\mathbf{P I}^{*}$ & $\mathbf{P I}^{\star *}$ & $\mathbf{P I}^{\star * *}$ \\
\hline 0 & $1.53 \pm 0.04$ & $4.19 \pm 0.02$ & $6.8 \pm 0.2$ \\
1 & $1.47 \pm 0.01$ & $4.49 \pm 0.08$ & $6.78 \pm 0.05$ \\
2 & $1.39 \pm 0.01$ & $3.97 \pm 0.04$ & $6.20 \pm 0.08$ \\
3 & $1.36 \pm 0.01$ & $3.58 \pm 0.08$ & $6.24 \pm 0.01$ \\
4 & $1.37 \pm 0.04$ & $3.7 \pm 0.2$ & $5.85 \pm 0.01$ \\
5 & $1.59 \pm 0.05$ & $3.83 \pm 0.09$ & $6.06 \pm 0.02$ \\
6 & $1.42 \pm 0.01$ & $4.44 \pm 0.04$ & $6.23 \pm 0.03$ \\
7 & $1.37 \pm 0.02$ & $4.32 \pm 0.01$ & $6.18 \pm 0.06$ \\
8 & $1.32 \pm 0.03$ & $4.22 \pm 0.05$ & $5.98 \pm 0.03$ \\
\hline
\end{tabular}

Data are the mean of triplicates \pm standard deviation of three replicates with three fruits each; ${ }^{*}$ Contents obtained by the difference between total and soluble pectin, dosed by the method of McCready \& McComb (1952); ${ }^{* *}$ Extraction using cellulase; ${ }^{* * *}$ Extraction using cellulase + hemicellulase. 
pectin chains and may contribute, together with pectins, to the integrity of the cell wall.

\subsection{Enzymatic activity}

The activity of $\beta$-D-glucosidase was determined in fractions of the supernatant and sediment; however, the sediment was inactive. On the other hand, the activity in the supernatant using
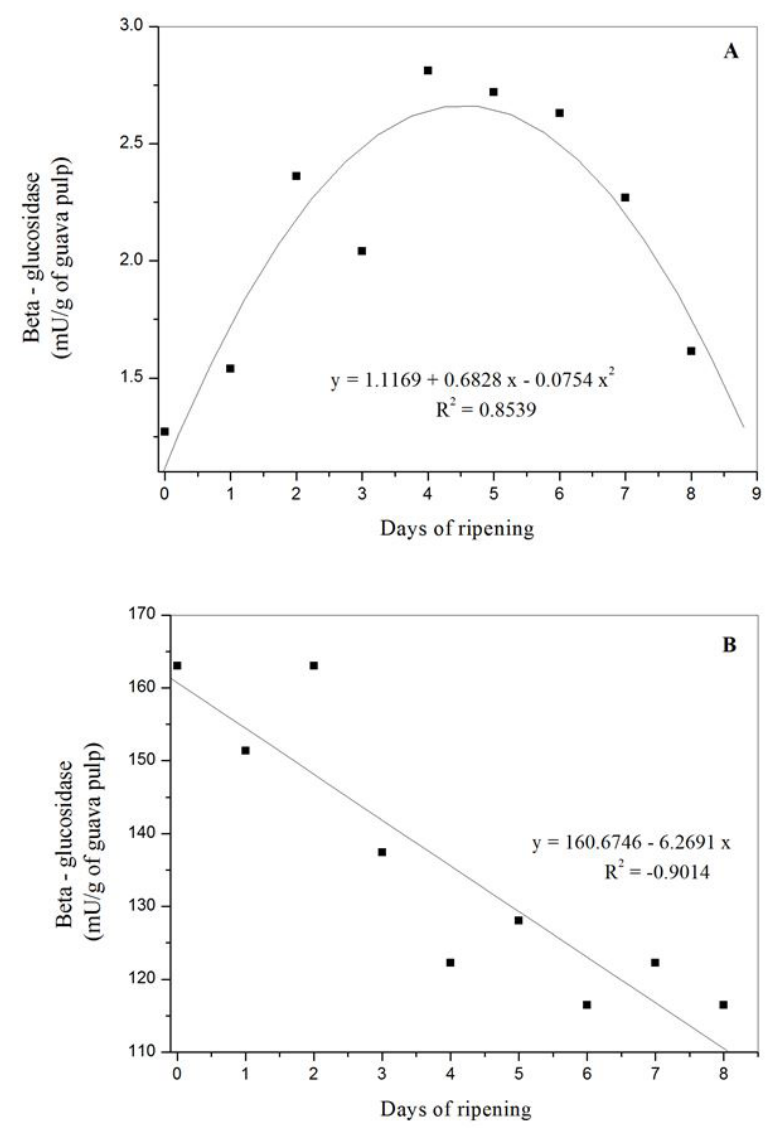

Figure 4. Activity of $\beta$-D-glucosidase in the supernatant using p-nitrophenyl- $\beta$-D-glucopyranoside as a substrate (A) and activity of $\beta$-D-glucosidase in the supernatant using salicin as a substrate (B), for guava cv. Pedro Sato during eight days of storage. the chromogenic substrate, $\mathrm{p}$-nitrophenyl- $\beta$-D-glucopyranoside, was very low, ranging from 1.27 to $1.61 \mathrm{mU} / \mathrm{g}$ fresh guava pulp, from day zero to the eighth day, respectively (Figure 4A).

It is possible to observe, in Figure $4 \mathrm{~A}$, that the activity of $\beta$-D-glucosidase increased until the fourth day of ripening, which coincides with the decrease in firmness over the same period (Figure 1). It suggests that this enzyme is responsible for the release of pectin from the cell wall. From the fourth day of activity of $\beta$-D-glucosidase, it decreased until the end of ripening, indicating a decrease in the enzyme substrate (pectin polymers).

The involvement of cell wall hydrolases in the loss of pulp firmness has been described in several fruits. Ketsa \& Daengkanit (1999) observed an increase in pectin solubilization with the decrease in pear firmness. There are studies on the low activity of $\beta$-glucosidase in the ripening of mango (Ali et al., 2004) and tomato (Konozy et al., 2012).

The activity of $\beta$-D-glucosidase was also determined, using salicin as a substrate. There was a decrease in activity in the supernatant during the eight days of ripening (Figure 4B), and the sediment was inactive.

The enzymatic assay in which salicin was used as a substrate showed a different behavior in relation to the assay in which p-nitrophenyl- $\beta$-D-glucopyranoside was used as a substrate (Figure 4A). Although the activity of $\beta$-D-glucosidase was detected, with a consequent increase in the contents of soluble pectin, other hydrolases possibly act, causing depolymerization of pectic fractions in the cell wall during ripening. Therefore, it is unlikely that this enzyme is the only responsible for changes in firmness. In fact, the process must involve a complex interaction of the activities of amylase and pectic enzymes, as well as galactosidases, with physicochemical changes in the wall (Tucker, 1993; Gwanpua et al., 2014).

The activity of esterase in the homogenized extract increased with the ripening of guava. A similar behavior was observed in the soluble fraction (SOB1) and in the membrane fraction (SED1) (Table 2), whose sum recovered $65.6 \%$ of the activity of the homogenate. The esterase in guava, obtained in this study, is predominantly located in the membrane, with an average of $57 \%$ of the activity, against $8.61 \%$ in the soluble fraction.

Table 2. Activity of esterase in $\mathrm{mU} / \mathrm{g}^{\star}$ fresh pulp in the extracts homogenized, soluble and membrane.

\begin{tabular}{|c|c|c|c|c|c|c|c|}
\hline \multirow[b]{2}{*}{ Day } & \multicolumn{7}{|c|}{ Activity of esterase ${ }^{*}$} \\
\hline & Homogenized & Soluble (SOB1) & $\%$ sum & $\begin{array}{c}\text { Membrane } \\
\text { (SED1) }\end{array}$ & $\%$ sum & Sum SOB1+SED1 & $\%$ recuperation \\
\hline 0 & $638 \pm 23$ & $63 \pm 4$ & 9.90 & $604 \pm 18$ & 94.60 & 666.61 & 104.52 \\
\hline 2 & $1,349 \pm 66$ & $87 \pm 4$ & 6.45 & $761 \pm 31$ & 56.40 & 848.22 & 62.90 \\
\hline 3 & $1,491 \pm 74$ & $103 \pm 6$ & 6.88 & $1,065 \pm 34$ & 71.40 & $1,167.40$ & 78.31 \\
\hline 4 & $1,695 \pm 84$ & $123 \pm 7$ & 7.25 & $871 \pm 36$ & 51.40 & 993.50 & 58.64 \\
\hline 6 & $1,522 \pm 61$ & $144 \pm 6$ & 9.44 & $542 \pm 30$ & 35.60 & 685.70 & 45.01 \\
\hline 7 & $1,607 \pm 67$ & $153 \pm 8$ & 9.52 & $582 \pm 26$ & 36.20 & 735.24 & 45.83 \\
\hline 8 & $1,614 \pm 96$ & $192 \pm 7$ & 11.90 & $815 \pm 23$ & 50.5 & $1,007.11$ & 62.40 \\
\hline Mean & & & $9 \pm 2$ & & $57 \pm 19$ & & $66 \pm 19$ \\
\hline
\end{tabular}

Results are the mean and standard deviation of the mean of 3 replicates with three fruits each; ${ }^{\star}$ A milliunit was defined as the amount of enzyme capable of catalyzing the release of 1 micromole of $\alpha$-naphthol per minute under the assay conditions. 
The increase in the activity of soluble esterase during ripening and consequent decrease in the activity of membrane esterase from the third day (Table 2) is an indicative that the cell wall is disorganizing with ripening, and releasing these enzymes, which become soluble, causing a decrease in the loss of fruit firmness by the action of hydrolytic enzymes. Some cell wall hydrolases increase their activity during ripening, and this increase is coincident with the softening of the fruit (Pinto et al., 2013).

With the treatment of the membrane fraction (SED1) with Triton X-100, the percentage of solubilization was $137.40 \pm 31.60 \%$, indicating that this enzyme may be associated with the cell membrane (integral or peripheral protein) of guava pulp cells. The fraction SED2 showed no esterase activity.

The high activity of membrane/cell wall esterases after the treatment of the membrane fraction (SED1) with Triton X-100, caused the hydrolysis of cross-links between pectin chains and between pectin chains and other polymers, releasing pectin polymers which, probably by the action of $\beta$-D-glucosidase, migrate into the cell until the fourth day of ripening.

In the case of guava, the explanation for the rapid decrease in firmness is probably due to the joint action of the PME, other esterases and $\beta$-D-glucosidase, identified in this study, which release cell wall pectin polymers.

\section{Conclusions}

The addition of the enzymes cellulase and hemicellulase in the pectin extraction in fruits of Psidium guajava revealed higher contents of this polyssacaride that the ones reported in literature, highlighting pectin as the responsible for the firmness of these fruits at more adequate contents.

The phenolic compounds gallic acid, catechin, and epigallocatechin gallate were identified and their content increased with fruit maturation and this might be related with the interrelation of the pectin chains in P. guajava fruits.

$\beta$-D-glucosidase was identified as one of the responsible enzymes for the maturation of $P$. guajava fruits, probably by hydrolysis of the crosslink between pectin chains which favors fruit maturation. Thus, studies about possible inhibitory effects of this enzyme in P. guajava fruits may reveal an important tool to reduce pectin release and early maturation of these fruits.

\section{Acknowledgements}

The authors would like to thank Fundação de Amparo à Pesquisa do Estado de Minas Gerais (FAPEMIG), Coordenação de Aperfeiçoamento de Pessoal de Nível Superior (CAPES) and Conselho Nacional de Desenvolvimento Científico e Tecnológico $(\mathrm{CNPq})$, for the grants provided.

\section{References}

Abreu, J. R., Santos, C. D., Abreu, C. M. P., \& Castro, E. M. (2012a). Histochemistry and morphoanatomy study on guava fruit during ripening. Food Science and Technology (Campinas), 32(1), 179-186. http://dx.doi.org/10.1590/S0101-20612012005000019.
Abreu, J. R., Santos, C. D., Abreu, C. M. P., Corrêa, A. D., \& Lima, L. C. O. (2012b). Sugar fractionation and pectin content during the ripening of guava cv. Pedro Sato. Food Science and Technology (Campinas), 32(1), 156-162. http://dx.doi.org/10.1590/S0101-20612012005000029.

Ali, Z. M., Chin, L. H., \& Lazan, H. (2004). A comparative study on wall degrading enzymes, pectin modifications and softening during ripening of selected tropical fruit. Plant Science, 167(2), 317-327. http://dx.doi.org/10.1016/j.plantsci.2004.03.030.

Association of Official Analytical Chemists - AOAC. (2012). Official methods of analysis of the Association of Official Analytical Chemist (19th ed.). Arlington: AOAC.

Bitter, T., \& Muir, H. M. (1962). A modified uronic acid carbazole reaction. Analytical Biochemistry, 4(4), 330-334. PMid:13971270. http://dx.doi.org/10.1016/0003-2697(62)90095-7.

Botelho, L. N. S., Rocha, D. A., Braga, M. A., Silva, A., \& Abreu, C. M. P. (2016). Quality of guava cv. 'Pedro Sato' treated with cassava starch and cinnamon essential oil. Scientia Horticulturae, 209(19), 214-220. http://dx.doi.org/10.1016/j.scienta.2016.06.012.

Cavalini, F. C., Jacomino, A. P., Trevisan, M. J., \& Miguel, A. C. A. (2015). Harvest time and quality of Kumagai and Paluma guavas. Revista Brasileira de Fruticultura, 37(1), 64-72. http://dx.doi. org/10.1590/0100-2945-013/14.

Chitarra, M. I. F., \& Chitarra, A. B. (2005). Pós-colheita de frutas e hortaliças: fisiologia e manejo (2nd ed.). Lavras: UFLA. 785 p.

Dolkar, D., Bakshi, P., Gupta, M., Wal, I. V. K., Kumar, R., Hazarika, T. K., \& Kher, D. (2017). Biochemical changes in guava (Psidium guajava) fruits during different stages of ripening. Indian Journal of Agricultural Sciences, 87(2), 257-260.

Gayathri, T., \& Nair, A. S. (2017). Biochemical analysis and activity profiling of fruit ripening enzymes in banana cultivars from Kerala. Food Measure, 11(3), 1274-1283. http://dx.doi.org/10.1007/s11694017-9505-6.

Ghai, K., Gupta, P. K., \& Gupta, A. K. (2016). Physiochemical behaviour changes during ripening in fruits of Trewia nudiflora Linn. Perspectives on Science, 8, 596-598. http://dx.doi.org/10.1016/j.pisc.2016.06.031.

Gill, K. S., Dhaliwal, H. S., Mahajan, B. V. C., Paliyath, G., \& Boora, R. S. (2016). Enhancing postharvest shelf life and quality of guava (Psidium guajava L.) cv. Allahabad Safeda by pre-harvest application of hexanal containing aqueous formulation. Postharvest Biology and Technology, 112, 224-232. http://dx.doi.org/10.1016/j.postharvbio.2015.09.010.

Gonçalves, B. J., Giarola, T. M. O., Pereira, D. F., Vilas Boas, E. V. B., \& Resende, J. V. (2016). Using infrared thermography to evaluate the injuries of cold-stored guava. Journal of Food Science and Technology, 53(2), 1063-1070. PMid:27162386. http://dx.doi.org/10.1007/ s13197-015-2141-4.

Gwanpua, S. G., Van Buggenhout, S., Verlinden, B. E., Christiaens, S., Shpigelman, A., Vicent, V., Kermani, Z. J., Nicolai, B. M., Hendrickx, M., \& Geeraerd, A. (2014). Pectin modifications and the role of pectin-degrading enzymes during postharvest softening of Jonagold apples. Food Chemistry, 158(1), 283-291. PMid:24731343. http:// dx.doi.org/10.1016/j.foodchem.2014.02.138.

Ketsa, S., \& Daengkanit, T. (1999). Firmness and activities of polygalacturonase, pectinesterase, b-galactosidase and cellulase in ripening durian harvested at different stages of maturity. Scientia Horticulturae, 80(3-4), 181-188. http://dx.doi.org/10.1016/S03044238(98)00242-8.

Konozy, E. H. E., Causse, M., \& Faurobert, M. (2012). Cell wall glycosidase activities and protein contente variations during fruit development and ripening in three texture contrasted tomato cultivars. Saudi 
Journal of Biological Sciences, 19(3), 277-283. PMid:23961187. http:// dx.doi.org/10.1016/j.sjbs.2012.04.006.

Linhares, L. A., Santos, C. D., Abreu, C. M. P., \& Corrêa, A. D. (2007). Chemical, physical and enzymatic transformations of guavas 'Pedro Sato' treated at postharvest with calcium chlorite and 1-methylciclopropone and stored under refrigeration. Ciência e Agrotecnologia, 31(3), 829-841. http://dx.doi.org/10.1590/S141370542007000300033.

Marques, T. R., Caetano, A. A., Simão, A. A., Castro, F. C. O., Ramos, V. O., \& Corrêa, A. D. (2016). Metanolic extract of Malpighia emarginata bagasse: phenolic compounds and inhibitory potential on digestive enzymes. Revista Brasileira de Farmacognosia, 26(2), 191-196. http://dx.doi.org/10.1016/j.bjp.2015.08.015.

McCready, R. M., \& McComb, E. A. (1952). Extraction and determination of total pectic materials in fruits. Analytical Chemistry, 24(12), 1986-1988. http://dx.doi.org/10.1021/ac60072a033.

Noelting, G., \& Bernfeld, P. (1948). Sur les enzymes amylolytiques: III., la $\beta$-amylase: dosage d'activité et contrôle de l'absence d'a-amylase. Helvetica Chimica Acta, 31(1), 286-290. PMid:18912399. http:// dx.doi.org/10.1002/hlca.19480310149.

Paiva, E. P., Lima, M. S., \& Paixão, J. A. (2009). Pectina: propriedades químicas e importância sobre a estrutura da parede celular de frutos durante o processo de maturação. Revista Iberoamericana de Polímeros, 10(4), 196-211.

Paniagua, C., Santiago-Doménech, N., Kirby, A. R., Gunning, A. P., Morris, V. J., Quesada, M. A., Matas, A. J., \& Mercado, J. A. (2017). Structural changes in cell wall pectins during strawberry fruit development. Plant Physiology and Biochemistry, 118, 55-63. PMid:28618373. http://dx.doi.org/10.1016/j.plaphy.2017.06.001.

Parr, A. J., Ng, A., \& Waldron, K. W. (1997). Ester-linked phenolic components of carrot cell walls. Journal of Agricultural and Food Chemistry, 45(7), 2468-2471. http://dx.doi.org/10.1021/jf960982k.

Pinto, L. K. A., Martins, M. L. L., Resende, E. D., Thièbaut, J. T. L., \& Martins, M. A. (2013). Activity of pectin methylesterase and $\beta$-galactosidase enzymes in 'Golden' papaya stored under diferente oxygen concentrations. Revista Brasileira de Fruticultura, 35(1), 1522. http://dx.doi.org/10.1590/S0100-29452013000100003.
Severo, J., Lima, C. S. M., Coelho, M. T., Rufatto, A. R., Rombaldi, C. V., \& Silva, J. A. (2010). Antioxidant capacity and phytochemical composition of physalis fruit (Physalis Peruviana, L.) during ripening and storage. Current Agricultural Science and Techonology, 16(1-4), 77-82.

Taiz, L., \& Zeiger, E. (2013). Fisiologia vegetal (5th ed.). Porto Alegre: Artmed. 820 p.

Tsai, P. J., Sun, Y. F., \& Hsiao, S. M. (2010). Strengthening the texture of dried guava slice by infiltration of phenolic compounds. Food Research International, 43(3), 825-830. http://dx.doi.org/10.1016/j. foodres.2009.11.019.

Tucker, G. A. (1993). Introduction. In G. B. Seymour, J. E. Taylor \& G. A. Tucker (Eds.), Biochemestry of fruit ripening (pp. 2-51). London: Chapman \& Hall. http://dx.doi.org/10.1007/978-94-011-1584-1_1.

Vieira, S. M. J., Raga, A., Benedetti, B. C., Oliveira, R. A., Di Marco, P. G., \& Scarponi, A. P. T. (2014). Effect of ultraviolet-C radiation on "Kumagai" guavas infested by Ceratitis capitata (Diptera-Tephritidae) and on physical parameters of postharvest. Scientia Horticulturae, 165, 295-302. http://dx.doi.org/10.1016/j.scienta.2013.11.015.

Vilas Boas, B. M., Alves, A. P., Alves, J. A., Rodrigues, L. J., Alves, T. C., \& Vilas Boas, E. V. B. (2013). Physical, chemical and biochemical characterization of pequi fruit harvested at different stages of development. Ciência Rural, 43(12), 2285-2290.

Wei, J., Qi, X., Cheng, Y., \& Guan, J. (2015). Difference in activity and gene expression of pectin-degrading enzymes during softening process in two cultivars of Chinese pear fruit. Scientia Horticulturae, 197(14), 434-440. http://dx.doi.org/10.1016/j.scienta.2015.10.002.

Werner, E. T., Oliveira, L. F. G. Jr., Bona, A. P., \& Gomes, T. D. U. H. (2009). Calcium chloride application in the post-harvest of guavas Cortibel. Bragantia, 68(2), 511-518. http://dx.doi.org/10.1590/ S0006-87052009000200026.

Xisto, A. L. R. P., Abreu, C. M. P., Corrêa, A. D., \& Santos, C. D. (2004). Texture of "Pedro Sato" guavas submitted to the application of calcium cloride. Ciência e Agrotecnologia, 28(1), 113-118. http:// dx.doi.org/10.1590/S1413-70542004000100015.

Zonta, E. P., \& Machado, A. A. (1991). Manual do Saneste: sistema de análise estatística para microcomputadores (102 p.). Pelotas: UFPel. 